\title{
Traffic Police Effectiveness and Efficiency Evaluations, an Overview of Methodological Considerations
}

\author{
Habibollah Rahimi, ${ }^{1}$ Seyed Saeed Hashemi Nazari, ${ }^{2}$ Hamid Soori, ${ }^{2,}$ Seyed Abbas Motevalian, ${ }^{3}$ \\ Eskandar Momeni, ${ }^{4}$ and Adel Azar ${ }^{5}$ \\ ${ }^{1}$ Department of Epidemiology, School of Health, Shahid Beheshti University of Medical Sciences, Tehran, IR Iran \\ ${ }^{2}$ Department of Epidemiology, Safety Promotion and Injury Prevention Research Center, School of Public Health, Shahid Beheshti University of Medical Sciences, Tehran, IR \\ Iran \\ ${ }^{3}$ Department of Epidemiology, School of Health, Iran University of Medical Sciences, Tehran, IR Iran \\ ${ }^{4}$ Traffic Police of Islamic Republic of Iran, Tehran, Iran \\ ${ }^{5}$ Department of Management, Faculty of Management and Economics, Tarbiat Modares University, Tehran, Iran \\ "Corresponding author: Hamid Soori, Safety Promotion and Injury Prevention Research Center, Shahid Beheshti University of Medical Sciences, Tehran, IR Iran. Tel: \\ +98-9133611401, Fax: +98-2122439980, E-mail: hsoori@yahoo.com
}

Received 2016 February 05; Revised 2016 June 25; Accepted 2016 June 26.

\begin{abstract}
Context: Every government implements various policies to mitigate road traffic injuries (RTIs). Many of these interventions are performed by traffic police. To evaluate effectiveness and efficiency of police enforcement, numerous studies have been conducted. Potential capabilities of epidemiology could get opportunity to improve these studies. The aim of this study was to extract and discuss some related methodological points of traffic police effectiveness and efficiency from related studies, in view of epidemiology discipline.

Evidence Acquisition: Related articles were searched with "traffic police", "effectiveness", "efficiency" and "road safety" keywords in ScienceDirect, PubMed and Safetylit databases. Related papers were selected and read carefully to summarize and discuss the epidemiological points with aims of giving clues to improve quality of studies.

Results: From a total of 797 articles, 20 were eligible which among them 17 articles were about effectiveness and 3 of them were about efficiency evaluations. Discussed points were the method of study, taking a holistic view to all positive and negative side effects, desired inputs and outputs, relation pattern between police enforcement and outcome and potential confounders.

Conclusions: Better understanding of the effectiveness and efficiency mechanism and having valid evaluation required considering specific theories and points in this field. Applying a dynamic approach with considering epidemiological concepts and sophisticated statistical models could improve quality of studies in this field.
\end{abstract}

Keywords: Police, Epidemiology, Effectiveness, Efficiency

\section{Context}

Studying distributions and determinants of health- related states and events could help to treat them. Knowledge of disease control improves by applying methodological principles of epidemiology. Evaluation of public health programs is one of them (1).

Road traffic injuries (RTIs), as the 9th leading cause of burden of disease (DALYs) and death in the world (2), have imposed governments to invest funds and implement different programs. For instance, a road traffic accident (RTA) rate in an urban area of Kashan county was measured 2.3\% in a year (3) or direct cost of treatment among fatal traumatic brain injuries (caused by RTAs) during five years in Shiraz imposed 511,000 USD in Iran (4). Director of the main programs is police administrations that evaluating their effectiveness and efficiency is necessary. Effectiveness is defined as "the extent to which a particular health tech- nology (medical, device, drug, procedure, health program or health service, including intervention) does what it is intended to do (i.e. leads to a beneficial health outcome or result) when it is provided under clinical practice conditions or in the field" (5). Also, efficiency is defined as "the relationship between resources (capital and labor) and health outcome" (6).

As numerous studies have been conducted on the effectiveness and efficiency of traffic police enforcement, review of related epidemiological points could augment their quality (7-16).

The aim of this study was to extract some methodological aspects of traffic police's effectiveness and efficiency in view of epidemiology discipline. 


\section{Evidence Acquisition}

Every original article about a direct effect of police enforcements on RTAs, RTIs and driving behaviors with keywords of "traffic police", "effectiveness", "traffic police”, "efficiency" and "road safety performance" was searched in ScienceDirect, PubMed and Safetylit databases without any time restrictions. Other road safety interventions were excluded (e.g. speed humps, speed camera and law legislations).

According to the titles and abstracts, interested articles were selected based on the aims of the studies about effectiveness and efficiency evaluation of direct police activity, without any restriction in the time of study, duration, outcome and method of the study. Then related articles were reviewed carefully and summarized in a table and mentioned methodological and theoretical specific points in them were extracted, without any appraising the quality of studies. The extracted points were presented in a paper, while considering epidemiological principles. They were discussed to attain conclusions and prepare a summarized paper to improve quality of studies in this field.

\section{Results}

From a total of 797 obtained articles, 20 were eligible (three ones about police efficiency and seventeen about effectiveness), which had been published from 1982 to 2014.

All of the efficiency studies had ecological designs. The input variables were the number of detected violations during road traffic controls, motor vehicles/1000 inhabitants, etc. The output variables were the number of alcohol examination, temporary confiscation of driving license, and road accident involving minor, serious injury and fatal crashes.

Designs of the effectiveness studies were community trials (11), ecological studies (5) and quasi-experience (1) with the period of the study from four weeks to nine years. Different input variables were used, such as comparison between methods of performing law enforcement and their intensities, police activity report sheets and frequency of patrolling, etc. The output variables were driving speeds and other violations such as not using seat belts, etc. Other details are presented in Table 1.

\section{Disccusion}

\subsection{Type of the Study}

Control of traffic violations is one of the main outcomes of traffic police enforcement. In a theoretical view that should be considered as the social activity and treated in social context $(17,18)$. Measuring the social context as an individual characteristic is not meaningful and required global measurement as one of the three measurement levels of ecological study (19).

Other reason that confirms adopting ecological studies or community trials refers to the consequence of police activity on population. Ross issued to it as a general deterrence effect of introduced punishment on other potential violators (20).

Applying other study methods require enough variability of favored variable(s) (e.g. rule compliance, RTAs, police apprehension levels) between individuals, regions or periods for distinguishing intervention effects. In some cases, because of high homogeneity in a society, it is not possible to find enough variability. For example in Norway with helmet use of $99 \%$, because of high homogeneity, finding enough evidence about a desired effect of police intervention may not be attainable (21).

In efficiency studies similar to effectiveness evaluations, it is not possible neither to assign inputs (police enforcement) to drivers nor isolate confounding factors, such as road infrastructures from them. Therefore, it requires ecological studies or community trials to meet the study goals.

4.2. Taking a Holistic View to All Positive and Negative Side Effects

In general, reduction of traffic violations, RTAs and RTIs are the result of traffic police enforcement. However, alongside those favored outcomes there are other side effects which may occur. Therefore, to have a universal effectiveness and efficiency evaluation, considering them is necessary. For instance, reducing speed limits may increase travel times, therefore considering it is necessary for prioritizing various interventions. In this issue, Elvik called them as the marginal benefits, which could be assessed in terms of current official monetary valuations. Some of them listed as travel time, vehicle operating costs, road accidents, traffic noises and air pollutions. For more details see Elvik, 2003 (21).

\subsection{Selecting Inputs and Outcomes}

Evaluation of effectiveness and efficiency of traffic police performance required one or more sensitive variables.

Traffic safety like other cases have its specific indicators that true selection of them is necessary for valid evaluation. Road traffic accidents have been recognized as the final outcomes of traffic safety which express with injury, death and vehicle damage.

These indicators have their limitations such as the effect of motorization levels and population size on their values, low sensitivity to changes in restricted area and area 
with rare events, taking different values by using different denominators (i.e. population, registered vehicles, licensed driver numbers, etc), changing the area safety rank and the effects of random fluctuations on the injury and death rate without meaningful interpretation to show declining or rising trends of risk. Moreover, injury and death indicators are affected by road infrastructures, medical emergency and culture of society.

Therefore, indicators with ability of crash and injury count and explanation of accident process while considering other affecting factors are required. Using these indicators in comparison of different regions and countries could give insight about specific clues to modify the traffic policies and performance in effectiveness and efficiency studies $(22,23)$.

In this issue, there have been conducted a series of consecutive studies, called SUNflower aimed to determine a benchmark country among the clusters of similar European countries. Applied indicators were determined by a collaborative team of experts with ability of detecting the best effective measures. Furthermore, it could rank countries while considering the contributing factors. Those comprehensive comparisons introduced realistic targets for the weaker countries, by learning from more successful country. The rationale of selected indicators was based on the comprehensive understanding of traffic safety and causality chain. For more details refer to Wegman et al. 2009 (23).

Furthermore, in other studies different indicators with local and national applications have been used $(8,13,23-35)$. Look at the Table 2 that was designed based on the structure of Shen's table (14).

When a set of indicators as the inputs or outputs is used to determine the order of the region's safety score or determine the ratio of outputs to inputs in efficiency studies, its value may be changed according to the used indicators. To avoid this problem and have a holistic view to road safety, it is better to use a composed index with a cluster of different indicators. To combine different indicators, it is necessary to assign weight to them. To do this there have been proposed different methods such as factor analysis, analytic hierarchy process, budget allocation, data envelopment analysis and equal weighting (24). There is a methodological guideline to construct composite indicators and make an index (36).

In addition, proper interpretation of any evaluations requires considering some aspects such as enforcement duration, relative enforcement changes compared to the baseline level and campaign education.

\subsection{Pattern of Police Enforcement and Outcomes Relation}

There is an S-shape relation between police presence levels and RTAs (37). When there is no enforcement, RTAs are at a highest level. After police recruitment, until attaining to a perceived level of police presence by drivers, RTAs do not change. Then increasing the police presence has an effect on its reduction until it reaches to a level that is not induced by driver violations. In this phase police increasing presence will not be effective. In Elvik's metaanalysis, it was mentioned as the marked threshold (38). He concluded negative nonlinear relation between police enforcement and traffic violations (Figure 1) (39). Therefore, it seems that there is an optimum level. For resource management in efficiency evaluations, recognition of this level as the best productive zone is useful. In addition, understanding this relation is necessary for applying suitable statistical models.

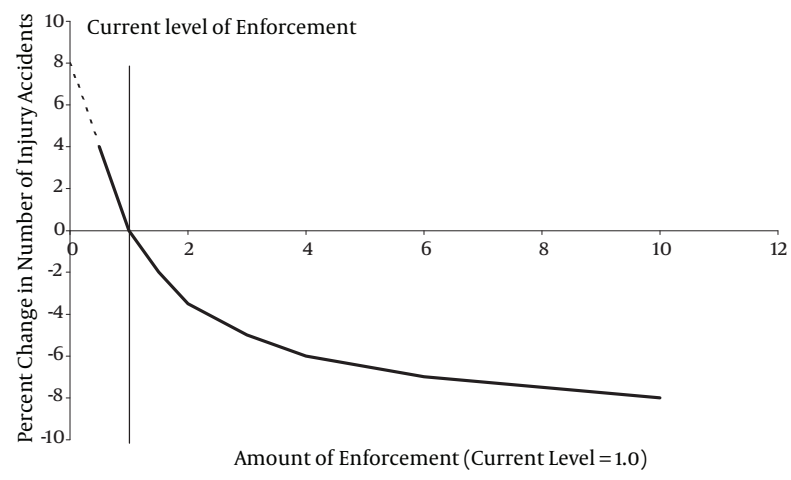

Figure 1. Relation Between the Amount of Enforcement and Percentage Change in the Number of Injury Accidents, Adopted from Elik, 2001 (39)

Stability of this relation over time is another issue. According to the game theory, abiding traffic law is not just a consequence of driver's judgment about tradeoff between violation utility and police punishment as a one-way effect of police enforcement. Instead, the driver and the police jointly and dependently interacts each other's decision (40). For instance when people drive over the speed level (a risk factor of RTAs) police reacts to this increasing violation by performing different ways such as increasing manpower along the roadside, more intercepting offender drivers and penalizing or seizing them or by increasing penalty fees. Police decision is the consequence of driver behaviors. This reaction of police causes decision of drivers by more abiding speed limit through apprehension of police punishment that decreases police's offence detections. Then police reduce its enforcement and again because of lowering apprehension level, speed violation increase (41, 
42). These input and output fluctuations affect the effectiveness and efficiency score, over time. Figure 2 shows those relations.

Risk compensation is another factor affecting the relation between police intervention and driving behaviors. Drivers adjust their behaviors according to a perceived risk. When they perceived more risk(e.g. driving in adverse weather) they are more careful. In contrast when they protect themselves, for instance using a helmet, fastening a seat belt or driving by anti-lock brakes cars they may take more dangerous behaviors (43-45). When police persuades or enforces using a seat belt or helmet, this phenomenon may decline the effectiveness and efficiency value because of increasing other dangerous behaviors. Elvik pointed out to this as the road-user behavioral adaptation. In occasions, the road safety measures modify some risk factors but because of an offsetting effect of behavioral adaptation some other risky behaviors may increase (46). These relations are depicted in Figure 3.

\subsection{Approach of Survey}

To study accidents there are three approaches including sequential modeling, epidemiological models and system models (47). These approaches are compared by Delorme and Lassarre, 2014 (48).

They pointed out that in sequential modeling the accident is a result of related events, which ordered sequentially and are useful for detailed investigations.

In an epidemiological approach, accident is the consequence of causal relation between different factors. Combined relations determine frequency and severity of an accident. In this approach, a holistic interaction between different factors does not consider. This shortcoming is treated with system models.

To conduct the system models, instead of causal mechanism between separate factors in an epidemiological approach we could find interrelations and dynamic effects of causal factors. This approach was used in a study about evaluating policies for traffic violations (49). Considering to aforementioned theories and properties of relations between various factors over time, it seems adopting a dynamic approach is better.

\subsection{Considering Potential Confounders in Adopted Studies}

In occasions we do not access to the native or local findings. Therefore, we use results of other settings. In these cases some factors including driver behaviors, culture, road infrastructure and vehicle characteristics have affected the findings. In fact, every country has its specific complex that can have a significant effect on the effectiveness and efficiency findings.
In summary, relations between factors affecting the police activity could be depicted as below:

Other limitations refer to variation in study design, quality of data in different studies, study duration and target groups.

Even using internal evaluations requires considering probable bias. Regression to mean is one of them that occur following intervention in a high risk area. This causes over estimation of intervention effects, whilst because of regressed risk, some of attributed results have been occurred spontaneously. Therefore, expecting achievement of other study results in areas with less risk may not be corrected.

Against regression to mean bias, spillover phenomenon induces underestimation of police effectiveness and efficiency in comparing two adjacent areas or consecutive periods. Activity of police in a region can have a significant effect on driving behaviors in adjacent areas or periods, named the hallo effect. In a study about photo-radar effect on speed and number of collisions, moreover reduction in number of collisions in enforcement segments ( $14 \pm 11 \%)$, in near area there were $19 \pm 10 \%$ reduction rate, too (50).

Autocorrelation is another issue that emerges in comparing RTAs between nearby regions. Due to other unknown or unmeasured factors these regions are more similar (19). These low variability causes underestimation of effectiveness and efficiency in nearby regions.

In this paper some of the important methodological points of traffic police effectiveness and efficiency were discussed. Lack of a specific framework to conduct the effectiveness and efficiency study does not get enough assurance about covering all related aspects. Therefore, one of the limitations of this study may be neglecting some points. The next limitation refers to restricted search in three databases, instead of all databases and since the aim of the study was reviewing the methodological points and was not meta-analysis or systematic review, it does not a matter.

\section{Footnotes}

Authors' Contribution: Habibollah Rahimi determined and conducted search strategy and reviewed articles. He also participated in drafting of the manuscript. Hamid Soori, Seyed Saeed Hashemi Nazari, and Seyed Abbas Motevalian contributed to discussing and appraising the context of the manuscript and in drafting. Eskandar Momeni and Adel Azar contributed to discussing about some of theoretical concepts.

Funding/Support: This study was part of the literature review of Habibollah Rahimi's Ph.D dissertation, the student 


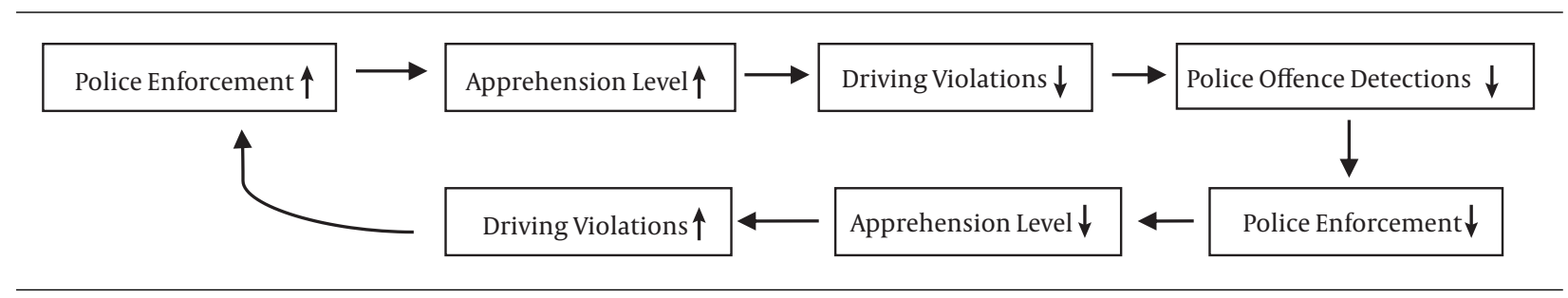

Figure 2. Schematic Diagram of the Game Theory

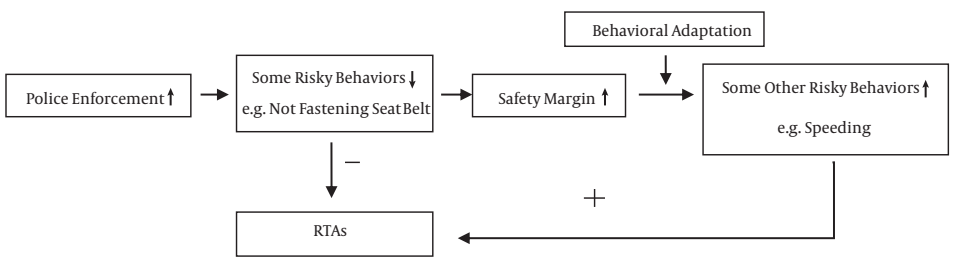

Figure 3. Schematic Diagram of the Risk Compensation Theory

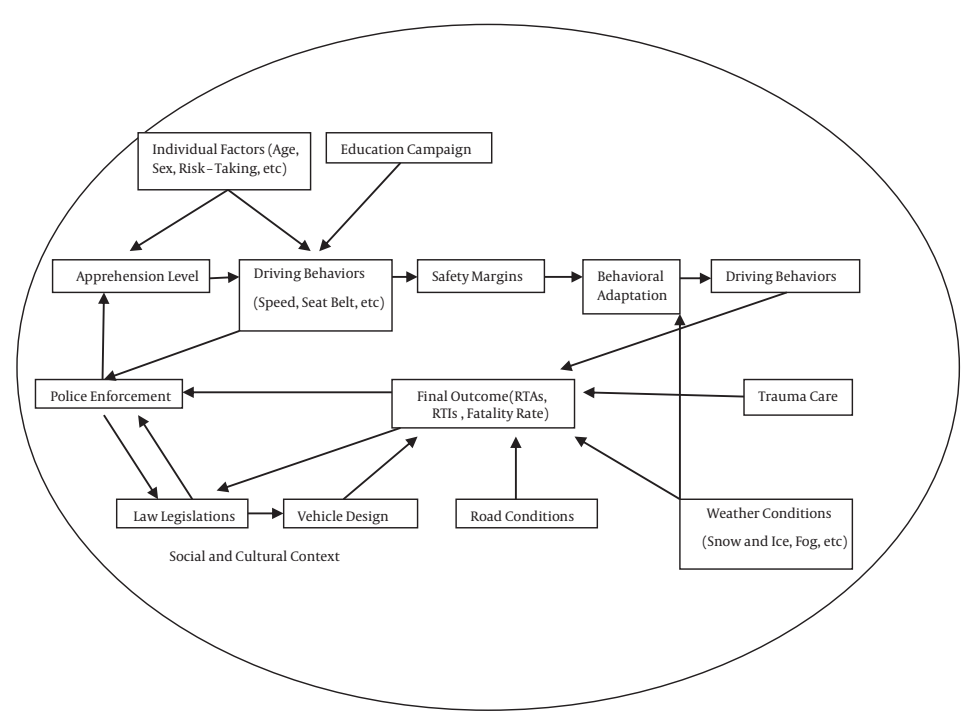

Figure 4. Schematic Diagram of Factors Affecting the Police Activity

of epidemiology in Shahid Beheshti University of Medical Sciences. The authors declared there were no funds to support this study.

\section{References}

1. Mannering FL, Bhat CR. Analytic methods in accident research: methodological frontier and future directions. Anal Methods Accid Res. 2014;1:1-22.

2. Mathers C, Fat DM, Boerma JT. The global burden of disease: 2004 update. Geneva: WHO; 2008.

3. Mahdian M, Sehat M, Fazel MR, Moraveji AR, Mohammadzadeh M. Epidemiology of urban traffic accident victims hospitalized more than
24 hours in a level III trauma center, Kashan County, Iran, during 20122013. Arch Trauma Res. 2015;4(2).

4. Kavosi Z, Jafari A, Hatam N, Enaami M. The economic burden of traumatic brain injury due to fatal traffic accidents in shahid rajaei trauma hospital, shiraz, iran. Arch Trauma Res. 2015;4(1):22594. doi: 10.5812/atr.22594. [PubMed: 25834791].

5. Boslaugh S. Encyclopedia of Epidemiology. New York: SAGE; 2008.

6. Last JM, Greenland S, Hernan M, Silva IS. In: A Dictionary of Epidemiology. Porta M, editor. New York: Oxford University Press; 2001.

7. De Waard D, Rooijers T. An experimental study to evaluate the effectiveness of different methods and intensities of law enforcement on driving speed on motorways. Accident Anal Prev. 1994;26(6):751-65.

8. Walter L, Broughton J, Knowles J. The effects of increased police enforcement along a route in London. Accid Anal Prev. 2011;43(3):1219-27. doi: 10.1016/j.aap.2011.01.003. [PubMed: 21376921]. 
9. Goldenbeld C, van Schagen I. The effects of speed enforcement with mobile radar on speed and accidents. An evaluation study on rural roads in the Dutch province Friesland.Accid Anal Prev. 2005;37(6):113544. doi: 10.1016/j.aap.2005.06.011. [PubMed: 16051180].

10. Newstead SV, Cameron MH, Leggett LMW. The crash reduction effectiveness of a network-wide traffic police deployment system. Accident Anal Prev. 2001;33(3):393-406.

11. Hakkert AS, Gitelman V, Cohen A, Doveh E, Umansky T. The evaluation of effects on driver behavior and accidents of concentrated general enforcement on interurban roads in Israel. Accid Anal Prev. 2001;33(1):43-63. [PubMed: 11189121].

12. Yannis G, Papadimitriou E, Antoniou C. Multilevel modelling for the regional effect of enforcement on road accidents. Accid Anal Prev. 2007;39(4):818-25. doi:10.1016/j.aap.2006.12.004. [PubMed: 17274938].

13. Egilmez G, McAvoy D. Benchmarking road safety of U.S. states: a DEA-based Malmquist productivity index approach. Accid Anal Prev. 2013;53:55-64. doi: 10.1016/j.aap.2012.12.038. [PubMed: 23376545].

14. Shen Y, Hermans E, Ruan D, Wets G, Brijs T, Vanhoof K. Road safety performance evaluation based on a multiple layer data envelopment analysis model. IRTAD. Seoul. 2009. pp. 315-23.

15. Hermans E, Brijs T, Wets G, Vanhoof K. Benchmarking road safety: lessons to learn from a data envelopment analysis. Accid Anal Prev. 2009;41(1):174-82. doi: 10.1016/j.aap.2008.10.010. [PubMed: 19114152].

16. Aristovnik A, Seljak J, Mencinger J. Relative efficiency of police directorates in Slovenia: A non-parametric analysis. Expert Syst Appl. 2013;40(2):820-7.

17. Quimby A, Downing C, Callahan C. Road users' attitudes to some road safety and transportation issues. UK: National Highway Traffic Safety Administration; 1991.

18. Grayson G. Driver behaviour. Proceedings of the Safety 91 Conference Wokingham. Berkshire. Transport Research Laboratory (TRL); .

19. Rothman KJ, Greenland S, Lash TL. Modern epidemiology. USA: Lippincott Williams \& Wilkins; 2008.

20. Laurence RH. Deterring the drinking driver. USA: National Highway Traffic Safety Administration; 1982. p. 129.

21. Elvik R. How would setting policy priorities according to cost-benefit analyses affect the provision of road safety?. Accident Anal Prev. 2003;35(4):557-70.

22. Wegman F, Oppe S. Benchmarking road safety performances of countries. Safety Sci. 2010;48(9):1203-11.

23. Wegman F, Commandeur J, Doveh E, Eksler V, Gitelman V, Hakkert S, et al. SUNflowerNext: Towards a composite road safety performance index. Netherlands: SWOV; 2008.

24. Hermans E, Van den Bossche F, Wets G. Combining road safety information in a performance index. Accid Anal Prev. 2008;40(4):1337-44. doi: 10.1016/j.aap.2008.02.004. [PubMed: 18606264].

25. Ren De Zhang Hong Bin Y, Fang SPL. The Study of DEA Evaluating Model on Road Traffic Safety. Proceedings of the World Congress on Engineering. UK. .

26. Gitelman V, Doveh E, Hakkert S. Designing a composite indicator for road safety. Safety Sci. 2010;48(9):1212-24. doi: 10.1016/j.ssci.2010.01.011.

27. Shen Y, Hermans E, Ruan D, Wets G, Vanhoof K, Brijs TA. Generalized multiple layer data envelopment analysis model. Proceedings of the 4th international conference on intelligent systems and knowledge engineering(ISKE'09). World Scientific; .

28. Hassan MN, Hawas YE, Maraqa MA. A holistic approach for assessing traffic safety in the United Arab Emirates. Accid Anal Prev. 2012;45:55464. doi:10.1016/j.aap.2011.09.009. [PubMed: 22269542].

29. Ma Z, Shao C, Ma S, Ye Z. Constructing road safety performance indicators using Fuzzy Delphi Method and Grey Delphi Method. Expert Syst Appl. 2011;38(3):1509-14. doi:10.1016/j.eswa.2010.07.062.

30. Papadimitriou E, Yannis G. Is road safety management linked to road safety performance?. Accid Anal Prev. 2013;59:593-603. doi: 10.1016/j.aap.2013.07.015. [PubMed: 23969271].

31. Chen F, Wang J, Deng Y. Road safety risk evaluation by means of improved entropy TOPSIS-RSR. Safety Sci. 2015;79:39-54. doi: 10.1016/j.ssci.2015.05.006.

32. Achterberg F. In: Raising Compliance with Road Safety Law. Road Safty Pin Report , editor. 1. UK: ETSC; 2007.

33. Munden JM. An experiment in enforcing the $30 \mathrm{mile} / \mathrm{h}$ speed limit UK: Road Research Laboratory; 1966. p. 28.

34. Cirillo JA. Interstate system accident research study II, interim report II-Public roads. 3. ; 1968.

35. Newstead SV, Bobevski I, Hosking S, Cameron MH. Evaluation of the Queensland road safety initiatives package. Australia: RSIP; 2004.

36. Nardo M, Saisana M, Saltelli A, Tarantola S, Hoffman A, Giovannini E. Handbook on constructing composite indicators. France: OECD; 2005. p. 158.

37. Oei HL. Automatic Speed Management in the Netherlands. Transport Res Rec. 1996;1560:57-64. doi: 10.3141/1560-09.

38. Elvik R. Cost-Benefit Analysis of Police Enforcement: Report ESCAPE project-Working Paper. ; 2001.

39. Elvik R. Cost-benefit analysis of police enforcement 2001. [cited Feb 2004]. Available from: http://virtual.vtt.fi/virtual/proj6/escape/ escape_wp1.pdf.

40. Bjørnskau T, Elvik R. Can road traffic law enforcement permanently reduce the number of accidents?. Accident Anal Prev. 1992;24(5):50720. doi: 10.1016/0001-4575(92)90059-r.

41. Shinar D, McKnight AJ. Human behavior and traffic safety. USA Springer; 1985. pp. 385-419.The effects of enforcement and public information on compliance.

42. Rothengatter T. Risk and the absence of pleasure: a motivational approach to modelling road user behaviour.Ergonomics. 1988;31(4):599607. doi: $10.1080 / 00140138808966702$.

43. Rodgers G. Reducing bicycle accidents: A reevaluation of the impacts of the CPSC bicycle standard and helmet use. J PROD LIABIL. 1988;11(4):307-17.

44. Janssen W. Seat-belt wearing and driving behavior: an instrumentedvehicle study. Accident Anal Prev. 1994;26(2):249-61.

45. Aschenbrenner KM, Biehl B. Improved safety through improved technical measures?. Germany: Transport Research Laboratory; 1994.

46. Elvik R. To what extent can theory account for the findings of road safety evaluation studies?. Accid Anal Prev. 2004;36(5):841-9. doi: 10.1016/j.aap.2003.08.003. [PubMed: 15203361].

47. Hollnagel E. Barriers and accident prevention. Aldershot, UK: Ashgate; 2004. p. 226.

48. Delorme R, Lassarre S. A new theory of complexity for safety research. The case of the long-lasting gap in road safety outcomes between France and Great Britain. Safety Sci. 2014;70:488-503. doi: 10.1016/j.ssci.2014.06.015.

49. Mehmood A. An integrated approach to evaluate policies for controlling traffic law violations. Accid Anal Prev. 2010;42(2):427-36. doi: 10.1016/j.aap.2009.09.004. [PubMed: 20159063].

50. Chen G, Meckle W, Wilson J. Speed and safety effect of photo radar enforcement on a highway corridor in British Columbia.AccidentAnal Prev. 2002;34(2):129-38. doi:10.1016/s0001-4575(01)00006-9.

51. Aristovnik A, Seljak J, Mencinger J. Performance measurement of police forces at the local level: A non-parametric mathematical programming approach. Expert Syst Appl. 2014;41(4):1647-53.

52. Bhalla K, Li Q, Duan L, Wang Y, Bishai D, Hyder AA. The prevalence of speeding and drunk driving in two cities in China: a mid project evaluation of ongoing road safety interventions. Injury. 2013;44 Suppl 4:S49-56. doi: 10.1016/S0020-1383(13)70213-4. [PubMed: 24377780].

53. Ferris J, Mazerolle L, King M, Bates L, Bennett S, Devaney M. Random breath testing in Queensland and Western Australia: examination of how the random breath testing rate influences alcohol related traffic crash rates. Accid Anal Prev. 2013;60:181-8. doi: 10.1016/j.aap.2013.08.018. [PubMed: 24060440].

54. Yannis G, Papadimitriou E, Antoniou C. Impact of enforcement on traffic accidents and fatalities: A multivariate multilevel analysis. Safety Sci. 2008;46(5):738-50. 
55. Jones AP, Sauerzapf V, Haynes R. The effects of mobile speed camera introduction on road traffic crashes and casualties in a rural county of England.J Safety Res. 2008;39(1):101-10. doi:10.1016/j.jsr.2007.10.011. [PubMed: 18325421].

56. Dula CS, Dwyer WO, LeVerne G. Policing the drunk driver: measuring law enforcement involvement in reducing alcohol-impaired driving. J Safety Res. 2007;38(3):267-72. doi:10.1016/j.jsr.2006.10.007. [PubMed: 17617235].

57. Tay R. The effectiveness of enforcement and publicity campaigns on serious crashes involving young male drivers: Are drink driving and speeding similar?. Accid Anal Prev. 2005;37(5):922-9. doi: 10.1016/j.aap.2005.04.010. [PubMed: 15925317].
58. Beenstock M, Gafni D, Goldin E. The effect of traffic policing on road safety in Israel. Accid Anal Prev. 2001;33(1):73-80. [PubMed: 11189123].

59. Vollrath M. Detecting intoxicated drivers in Germany - estimating the effectiveness of police tests. Accid Anal Prev. 2000;32(5):665-72. [PubMed: 10908139].

60. Vaa T. Increased police enforcement: effects on speed. Accid Anal Prev. 1997;29(3):373-85. [PubMed: 9183475].

61. Holland CA, Conner MT. Exceeding the speed limit: an evaluation of the effectiveness of a police intervention. Accid Anal Prev. 1996;28(5):587-97. [PubMed: 8899040].

62. Hauer E, Ahlin FJ, Bowser JS. Speed enforcement and speed choice. Accident Anal Prev. 1982;14(4):267-78. 
Table 1. List of Reviewed Studies

\begin{tabular}{|c|c|c|c|c|c|c|c|}
\hline Reference & Location & Study Goals & Study Design & Duration/Time & Inputs & Outputs & $\begin{array}{l}\text { Method of } \\
\text { Analysis }\end{array}$ \\
\hline (51) & Slovenia & $\begin{array}{l}\text { Relative efficiency } \\
\text { of police stations }\end{array}$ & Ecologic study & 2010 & $\begin{array}{l}\text { Number of } \\
\text { occupied } \\
\text { employment } \\
\text { posts, work } \\
\text { stations and police } \\
\text { vehicle radio } \\
\text { stations, and road } \\
\text { accidents }\end{array}$ & $\begin{array}{l}\text { Number of road } \\
\text { accidents } \\
\text { involving minor } \\
\text { and serious injury }\end{array}$ & $\begin{array}{l}\text { Data envelopment } \\
\text { analysis (DEA) }\end{array}$ \\
\hline (16) & Slovenia & $\begin{array}{l}\text { Measuring relative } \\
\text { efficiency of police } \\
\text { directories }\end{array}$ & Ecologic study & 2005 and 2010 & $\begin{array}{l}\text { Number of } \\
\text { violations } \\
\text { detected during } \\
\text { road traffic } \\
\text { controls, number } \\
\text { of motor } \\
\text { vehicles } / 1000 \\
\text { inhabitants }{ }^{\mathrm{a}} \text {, } \\
\text { length of public } \\
\text { roads }(2008) / \mathrm{km} 2\end{array}$ & $\begin{array}{l}\text { Number of alcohol } \\
\text { examination, } \\
\text { temporary } \\
\text { confiscation of } \\
\text { driving license }\end{array}$ & DEA \\
\hline (13) & USA & $\begin{array}{l}\text { Analyzing and } \\
\text { comparing the } \\
\text { road safety } \\
\text { performance of } \\
\text { U.S. states }\end{array}$ & Ecologic study & $2002-2008$ & $\begin{array}{l}\text { Highway safety } \\
\text { expenditures, } \\
\text { registered } \\
\text { vehicles, licensed } \\
\text { drivers, } \\
\text { vehicle-miles } \\
\text { traveled, total road } \\
\text { length, overall } \\
\text { road condition, } \\
\text { safety belt usage }\end{array}$ & Fatal crashes & $\begin{array}{l}\text { DEA-based } \\
\text { Malmquist index } \\
\text { model }\end{array}$ \\
\hline (52) & China & $\begin{array}{l}\text { Evaluating the } \\
\text { introduction of } \\
\text { the interventions } \\
\text { to road safety } \\
\text { improvements in } \\
\text { the two cities } \\
\text { (Suzhou and } \\
\text { Dalian) }\end{array}$ & Community trial & $\begin{array}{c}9 \text { months and } 100 \\
\text { days }\end{array}$ & $\begin{array}{l}\text { General awareness } \\
\text { raising campaigns } \\
\text { on the risks of } \\
\text { drink- driving and } \\
\text { speeding, a } 100 \\
\text { day social } \\
\text { marketing } \\
\text { campaign related } \\
\text { to drink driving } \\
\text { accompanied with } \\
\text { increased police } \\
\text { enforcement } \\
\text { activities }\end{array}$ & $\begin{array}{l}\text { Knowledge, } \\
\text { attitude and } \\
\text { perceptions (KAP) } \\
\text { about drink } \\
\text { driving, } \\
\text { prevalence of } \\
\text { drink-driving, } \\
\text { trends in } \\
\text { speeding, crashes } \\
\text { and injuries }\end{array}$ & $\begin{array}{l}\text { Percentage } \\
\text { difference }\end{array}$ \\
\hline (53) & Australia & $\begin{array}{l}\text { Exploring the } \\
\text { relationship } \\
\text { between monthly } \\
\text { random breath } \\
\text { testing (RBT) rates } \\
\text { (per 1000 licensed } \\
\text { drivers) and } \\
\text { alcohol-related } \\
\text { traffic crash } \\
\text { (ARTC) rates over } \\
\text { time }\end{array}$ & Ecologic study & 5 years & $\begin{array}{l}\text { Random breath } \\
\text { testing (RBT) }\end{array}$ & $\begin{array}{l}\text { Alcohol-related } \\
\text { traffic crashes }\end{array}$ & $\begin{array}{l}\text { Join point } \\
\text { regression } \\
\text { analysis, linear-log } \\
\text { OLS regression }\end{array}$ \\
\hline (8) & UK & $\begin{array}{l}\text { Measuring effects } \\
\text { of increased } \\
\text { enforcement and } \\
\text { publicity on } \\
\text { driving behaviors }\end{array}$ & Community trial & 4 weeks & $\begin{array}{l}\text { Count of police } \\
\text { vehicles passing } \\
\text { each observation } \\
\text { site, police } \\
\text { vehicles recorded } \\
\text { on CCTV passing } \\
\text { one junction and } \\
\text { activity sheets } \\
\text { completed by the } \\
\text { police officers } \\
\text { involved in } \\
\text { operation radar }\end{array}$ & $\begin{array}{l}\text { Vehicle speed, use } \\
\text { of seatbelts and } \\
\text { mobile phones }\end{array}$ & Not mentioned \\
\hline
\end{tabular}




\begin{tabular}{|c|c|c|c|c|c|c|c|}
\hline$(54)$ & Greece & $\begin{array}{l}\text { Quantification of } \\
\text { the effect of speed } \\
\text { and alcohol } \\
\text { enforcement on } \\
\text { both road } \\
\text { accidents and } \\
\text { fatalities and their } \\
\text { regional } \\
\text { variations }\end{array}$ & Ecologic study & 5 years & $\begin{array}{l}\text { The number of } \\
\text { alcohol controls } \\
\text { and speed } \\
\text { infringements }\end{array}$ & $\begin{array}{l}\text { The number of } \\
\text { road accidents } \\
\text { with casualties } \\
\text { and the related } \\
\text { fatalities }\end{array}$ & $\begin{array}{l}\text { Multilevel } \\
\text { modeling } \\
\text { technique, } \\
\text { poisson multilevel } \\
\text { modeling. }\end{array}$ \\
\hline (55) & UK & $\begin{array}{l}\text { The impacts on } \\
\text { crash and casualty } \\
\text { numbers } \\
\text { corresponding to } \\
\text { the introduction } \\
\text { of mobile speed } \\
\text { camera initiative } \\
\text { in the rural county }\end{array}$ & Ecologic study & 4 years & $\begin{array}{l}\text { Mobile speed } \\
\text { cameras }\end{array}$ & $\begin{array}{l}\text { Crashes involving } \\
\text { fatalities or } \\
\text { serious injuries }\end{array}$ & $\begin{array}{l}\text { Linear Regression, } \\
\text { percent difference }\end{array}$ \\
\hline$(56)$ & USA & $\begin{array}{l}\text { Whether the levels } \\
\text { of driving under } \\
\text { influence (DUI) } \\
\text { arrests, at the rates } \\
\text { they are typically } \\
\text { engaged in, have } \\
\text { any meaningful } \\
\text { impact on DUI } \\
\text { crashes }\end{array}$ & Ecologic study & $\begin{array}{l}2 \text { years }(2001 \text { and } \\
2003)\end{array}$ & $\begin{array}{l}\text { Proactive DUI } \\
\text { arrest rate }\end{array}$ & $\begin{array}{l}\text { DUI-related } \\
\text { crashes rate }\end{array}$ & $\begin{array}{l}\text { Pearson product } \\
\text { moment } \\
\text { correlation }\end{array}$ \\
\hline (12) & Greece & $\begin{array}{l}\text { Quantification of } \\
\text { the national and } \\
\text { regional effect of } \\
\text { police } \\
\text { enforcement on } \\
\text { road safety }\end{array}$ & Ecologic study & 1998-2002 & $\begin{array}{l}\text { The number of } \\
\text { alcohol controls } \\
\text { and speed } \\
\text { violations }\end{array}$ & $\begin{array}{l}\text { The number of } \\
\text { road accidents } \\
\text { with casualties as } \\
\text { well as } \\
\text { socioeconomic } \\
\text { parameters }\end{array}$ & $\begin{array}{l}\text { A multilevel } \\
\text { modeling } \\
\text { technique }\end{array}$ \\
\hline (57) & Australia & $\begin{array}{l}\text { Re-evaluate the } \\
\text { anti-drink driving } \\
\text { and anti-speeding } \\
\text { enforcement and } \\
\text { publicity } \\
\text { campaigns by } \\
\text { examining their } \\
\text { combined effects } \\
\text { on the total } \\
\text { number of serious } \\
\text { crashes involving } \\
\text { young male } \\
\text { drivers }\end{array}$ & Community trial & 6 years & $\begin{array}{l}\text { The number of } \\
\text { random breath } \\
\text { tests, traffic } \\
\text { infringement } \\
\text { notices (speeding } \\
\text { tickets), ad stock } \\
\text { for anti-drink } \\
\text { driving television } \\
\text { advertising and } \\
\text { the ad stock for } \\
\text { anti-speeding } \\
\text { publicity } \\
\text { campaign }\end{array}$ & $\begin{array}{l}\text { the total number } \\
\text { of serious crashes } \\
\text { involving young } \\
\text { male drivers }\end{array}$ & $\begin{array}{l}\text { Time-series model, } \\
\text { poisson model }\end{array}$ \\
\hline (9) & Netherlands & $\begin{array}{l}\text { Evaluation of the } \\
\text { speed and safety } \\
\text { effects of mobile } \\
\text { inconspicuous } \\
\text { speed cameras on } \\
\text { rural roads, along } \\
\text { with publicity and } \\
\text { communication } \\
\text { about the project }\end{array}$ & community trial & 5 years & $\begin{array}{l}\text { Speed } \\
\text { enforcement with } \\
\text { mobile radar from } \\
\text { an inconspicuous } \\
\text { police car with } \\
\text { additional } \\
\text { instruments in } \\
\text { latter years }\end{array}$ & $\begin{array}{l}\text { Mean speed and } \\
\text { the percentage } \\
\text { speed limit } \\
\text { violators, the } \\
\text { number of injury } \\
\text { and serious } \\
\text { accidents }\end{array}$ & $\begin{array}{l}\text { Repeated } \\
\text { measures ANOVA }\end{array}$ \\
\hline (58) & Israel & $\begin{array}{l}\text { Investigating both } \\
\text { the qualitative and } \\
\text { quantitative } \\
\text { effects of traffic } \\
\text { policing on road } \\
\text { safety }\end{array}$ & Ecologic study & 2 years & $\begin{array}{l}\text { The number of } \\
\text { police reports } \\
\text { issued for driving } \\
\text { offences }\end{array}$ & Accidents & $\begin{array}{l}\text { Poisson fixed } \\
\text { effect, poisson } \\
\text { random effect, } \\
\text { negative binomial } \\
\text { fixed effect, } \\
\text { negative binomial } \\
\text { random effect, } \\
\text { Tobit regression }\end{array}$ \\
\hline (11) & Israel & $\begin{array}{l}\text { Monitoring of } \\
\text { everyday police } \\
\text { operations on } \\
\text { driver's behavior, } \\
\text { attitudes and the } \\
\text { accident changes }\end{array}$ & Community trial & One year & $\begin{array}{l}11 \%-14 \% \text { increase } \\
\text { in staff and vehicle } \\
\text { fleet and a } 15 \% \\
\text { supplement of } \\
\text { enforcement tools }\end{array}$ & $\begin{array}{l}\text { Severe accidents, } \\
\text { all injury } \\
\text { accidents, severe } \\
\text { casualties and } \\
\text { drivers' attitudes }\end{array}$ & $\begin{array}{l}\text { A statistical model } \\
\text {, combining the } \\
\text { odds ratio and } \\
\text { longitudinal } \\
\text { methods, } \\
\text { generalized linear } \\
\text { model }\end{array}$ \\
\hline
\end{tabular}




\begin{tabular}{|c|c|c|c|c|c|c|c|}
\hline (10) & Australia & $\begin{array}{l}\text { Measuring the } \\
\text { crash effects of the } \\
\text { random road } \\
\text { watch program }\end{array}$ & $\begin{array}{c}\text { Quasi } \\
\text { experimental }\end{array}$ & 9 years & $\begin{array}{l}\text { Program coverage, } \\
\text { offences detected, } \\
\text { hours enforced }\end{array}$ & Crash changes & $\begin{array}{l}\text { Log-linear } \\
\text { regression, } \\
\text { Poisson } \\
\text { regression, } \\
\text { multiple linear } \\
\text { regression, trend } \\
\text { analysis }\end{array}$ \\
\hline (59) & Germany & $\begin{array}{l}\text { The effectiveness } \\
\text { of police tests in } \\
\text { finding driving } \\
\text { while intoxicated }\end{array}$ & Community trial & 6 months & $\begin{array}{l}\text { Random breath } \\
\text { test versus } \\
\text { ordinary breath } \\
\text { test (testing } \\
\text { suspected } \\
\text { intoxicated } \\
\text { drivers) }\end{array}$ & $\begin{array}{l}\text { Detection rate of } \\
\text { intoxicated drivers }\end{array}$ & $\begin{array}{l}\text { Comparison of } \\
\text { detection rate }\end{array}$ \\
\hline (60) & Norway & $\begin{array}{l}\text { Reducing } \\
\text { speeding behavior } \\
\text { on a stretch of } \\
\text { road by an } \\
\text { increase in police } \\
\text { enforcement }\end{array}$ & Community trial & 16 weeks & $\begin{array}{l}\text { Increase police } \\
\text { enforcement }\end{array}$ & $\begin{array}{l}\text { Average speed and } \\
\text { the percentage of } \\
\text { speeding drivers }\end{array}$ & $\begin{array}{l}\text { Multiple linear } \\
\text { regression }\end{array}$ \\
\hline (61) & UK & $\begin{array}{l}\text { Examining the } \\
\text { effect of road } \\
\text { safety campaigns } \\
\text { and enforcement } \\
\text { on behavior of } \\
\text { people breaking } \\
\text { the speed limits } \\
\text { and intentions to } \\
\text { speed }\end{array}$ & community trial & 13 weeks & $\begin{array}{l}\text { Police presence, } \\
\text { warning signs }\end{array}$ & $\begin{array}{l}\text { Vehicular speeds, } \\
\text { intentions to } \\
\text { speed in the future }\end{array}$ & $\begin{array}{l}\text { Two-way ANOVA, } \\
\text { 4-way ANOVA }\end{array}$ \\
\hline (7) & Netherlands & $\begin{array}{l}\text { Dose effect } \\
\text { evaluation of } \\
\text { police } \\
\text { enforcement with } \\
\text { different methods } \\
\text { of enforcement }\end{array}$ & Community trial & 4 and 12 weeks & $\begin{array}{l}\text { Three different } \\
\text { objective levels of } \\
\text { apprehension for } \\
\text { detected speeding } \\
\text { drivers, on-view } \\
\text { stopping } \\
\text { offenders } \\
\text { compared with } \\
\text { mailing of fines } \\
\text { with and without } \\
\text { delay }\end{array}$ & $\begin{array}{l}\text { Driving speed, } \\
\text { driver opinion } \\
\text { about speeding } \\
\text { and speed } \\
\text { enforcement }\end{array}$ & ANOVA \\
\hline (62) & Canada & $\begin{array}{l}\text { Obtain evidence } \\
\text { on the effect of } \\
\text { speed law } \\
\text { enforcement on } \\
\text { the speed choice } \\
\text { make by drivers } \\
\text { with considering } \\
\text { "distance" and } \\
\text { "time halo" effects }\end{array}$ & Community trial & Five weeks & $\begin{array}{l}\text { police cruiser } \\
\text { presence in } \\
\text { "upstream", } \\
\text { "enforcement" } \\
\text { and "downstream" }\end{array}$ & $\begin{array}{l}\text { Vehicular speeds } \\
\text { near enforcement } \\
\text { symbol, upstream } \\
\text { and downstream }\end{array}$ & $\begin{array}{l}\text { Speed percentile } \\
\text { comparison }\end{array}$ \\
\hline
\end{tabular}

${ }^{\mathrm{a}}$ Some of inputs were not discretionary. 
Table 2. List of Hierarchical Structure of Ever Used Road Safety Indicators

\begin{tabular}{|c|c|c|c|}
\hline & \multicolumn{2}{|c|}{ Indicator } & Description \\
\hline \multirow{13}{*}{ An overall Road Safety Index } & \multirow{7}{*}{ Final Outcome Indicators } & Personal Safety & Fatalities per Million Inhabitants \\
\hline & & \multirow{2}{*}{ Traffic safety } & $\begin{array}{l}\text { Fatalities per million passenger cars, } \\
\text { per } 10,000 \text { vehicles }\end{array}$ \\
\hline & & & per 10 billion passenger-km travelled \\
\hline & & Traffic injury and accident & $\begin{array}{l}\text { Injury accidents per fatality, the } \\
\text { number of serious injuries per million } \\
\text { inhabitants, slight injuries per million } \\
\text { inhabitants, crashes per million } \\
\text { inhabitants, accidents per } 10,000 \\
\text { vehicles, accidents per } 100,000 \text { people } \\
\text { and accidents per } 100 \mathrm{~km}\end{array}$ \\
\hline & & \multirow{3}{*}{ Vulnerable road users } & $\begin{array}{l}\text { Share of pedestrian fatalities out of } \\
\text { the total fatalities }\end{array}$ \\
\hline & & & $\begin{array}{l}\text { Share of bicyclist fatalities out of the } \\
\text { total fatalities }\end{array}$ \\
\hline & & & $\begin{array}{l}\text { Share of motorcyclist fatalities out of } \\
\text { the total fatalities }\end{array}$ \\
\hline & \multirow{6}{*}{ Safety performance Indicators } & Speed & $\begin{array}{l}\text { Median speed, average speeds, median } \\
\text { absolute deviation, \% drivers }>\text { legal } \\
\text { limit, \% drivers more than } 10 \mathrm{~km} / \mathrm{h}> \\
\text { limit }\end{array}$ \\
\hline & & Daytime running lights (DRL) & $\begin{array}{l}\% \text { usage of DRL per road and vehicle } \\
\text { type, legislation on DRL }\end{array}$ \\
\hline & & Alcohol & $\begin{array}{l}\text { \% drivers impaired by alcohol (> legal } \\
\text { limit), \% drivers impaired by drugs, } \\
\text { proportion of fatalities from crashes } \\
\text { involving at least } 1 \text { impaired road user }\end{array}$ \\
\hline & & Protective systems & $\begin{array}{l}\text { Daytime wearing rates of seat belts in } \\
\text { the front seats, daytime wearing rates } \\
\text { of seat belts in the rear seats, child } \\
\text { restrain rate, helmet by cyclists, } \\
\text { helmet by moped riders, helmet by } \\
\text { motorcyclists }\end{array}$ \\
\hline & & Human & $\begin{array}{l}\text { Drivers' training and licensing, } \\
\text { driving license less than } 3 \text { years, } \\
\text { fatigue driving rate, traffic violation, } \\
\text { laws broken by pedestrian at } \\
\text { intersection, number of driving } \\
\text { license delivered per vehicles }\end{array}$ \\
\hline & & Vehicles & $\begin{array}{l}\text { Average EuroNCAP score of the } \\
\text { passenger car fleet, median age of the } \\
\text { passenger car fleet, distribution of } \\
\text { vehicle age (\% > } 15 \text { years,...), } \\
\text { percentage of vehicles of maximum } \\
\text { five years old, median age of the } \\
\text { passenger car fleet, average } \\
\text { percentage occupant protection score } \\
\text { for new cars sold, average percentage } \\
\text { score of pedestrian protection for new } \\
\text { cars sold, renewal rate of passenger } \\
\text { cars, the implementation of seat belt } \\
\text { reminders in new cars, composition } \\
\text { of vehicle fleet (\% cars,...), share of } \\
\text { motorcycles in the vehicle fleet, share } \\
\text { of heavy goods vehicles in the vehicle } \\
\text { fleet }\end{array}$ \\
\hline
\end{tabular}




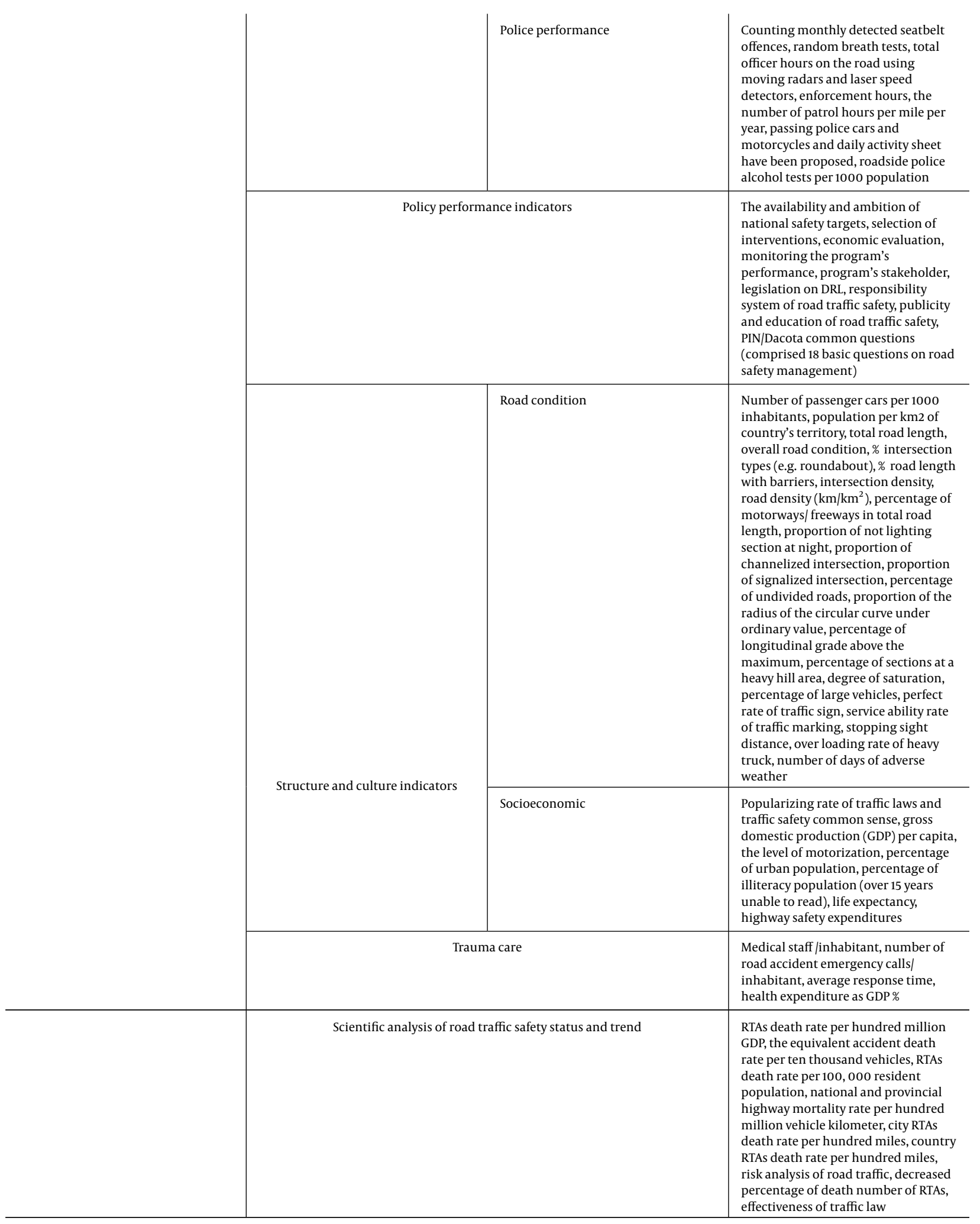

